\title{
Witch-Hunting in Assam: Myth or Reality
}

Lekha Borah $^{+*}$ and Madhushree Das ${ }^{*}$

\section{Abstract}

Assam, like many other parts across the country, often witnesses deaths, injuries, and miseries resulting from witch hunting, an atrocious practice and a socially sanctioned violence. Reiterated incidents of killings in the name of witch-hunting have alarmingly challenged the laws and have led to various anti-witch hunting programs. Often veiled under superstition, the factors that render this social menace unabated is a matter of grave concern for every conscious mind. Official records suggest 196 cases of the terrible violence to occur in the state between 1989-2014, but newspaper reports and other agencies present the actual social reality which echoes manifold of official records. The practice of witch-hunting, however, is not evenly distributed in all the areas of Assam, but have gripping roots in the customary beliefs of many tribal communities residing in the state. This research, therefore, is an attempt to illuminate the genesis of the witch hunt in Assam from the perspective of a crime having cross-community dimensions. Further, gaining insights from primary field survey and secondary data, it is evident that accessibility plays a trump card in this case of witchcraft in Assam along with the superstitious belief of the communities, intermingling with personal motives, illness and devious role of ojhas (village medicine men) which exaggerates the menace.

Keywords: Witch Hunt; Crime; Causes; Ojhas; Cross Community; Assam

\footnotetext{
${ }^{+}$Research Scholar, Department of Geography Gauhati University, Assam India

${ }^{*}$ Corresponding Author, Email: lekhaborah01@gmail.com

¥ Professor, Department of Geography Gauhati University, Assam, India

(C) 2019 Borah and Das. This is an Open Access article distributed under the terms of the Creative Commons Attribution License (http://creativecommons.org/licenses/by/2.0), which permits unrestricted use, distribution, and reproduction in any medium, provided the original work is properly cited.
} 


\section{Introduction}

The phenomenon of the witch hunt is not new to the society. Before the 18th Century, individuals ubiquitously in the world believed in indiscernible mystical forces; their incidence was sensed in even the most mundane facets of life (Bhattacharya, 1994). Flipping the pages of history gives testimonies to the early witch hunts of Europe, Scotland, Germany, Kingdom of Great Britain between 1450-1750, and in the middle ages (1750-1900), witch hunts of Hungary, Demark and Rome and more recently such activities were frequently witnessed in parts of South Africa, Cameroon, Congo, Gambia, Ghana, Kenya, Sierra Leone, Tanzania, Zambia, Papua New Guinea, Nepal and India (Booth, 2001). Interestingly enough, the roots of such superstitious practices lie in the most developed countries of the western world (Behringer, 2004, 14; Hsu, 1960; Kapur, 1983, 117).

With the advent of science and technology, this menacing practice is being wiped out if not totally in most of the developed parts of the world. But still, vast stretches of Asia, Africa, and Latin America, Zimbabwe, USA (Bhattacharya, 1994, 2; Behringer, 2004, 236) is battling out this grievous crime irrespective to the level of development (Bailey, 2017; Behringer, 2004, 18; Bernhard, 2010; Gibbs, 2012; Himugu, 2015; James, 2012; Nath, 2016; Knut, 2014; Snodgrass et. al., 2008).

Indian witchcraft that has existed from millennia (Bhattacharya, 1994) is not essentially accompanied by the violence that often characterises witch-hunting in other parts of the world. The states of Jharkhand, Chhattisgarh, and Haryana, Maharashtra, Madhya Pradesh, are prominent among them (Bhattacharya, 1994).

Witchcraft and witch-hunting have been a very long researched subject for many papers, monographs, and books, which dealt with differential dimensions of it (Banerjee, 2017; Chaudhuri, 2008; Chaudhuri, 2012; Chaudhuri, 2014; Das, 2015; Kapur, 1983; Rajaram, 1981). The usual conclusions derived out of the studies illuminate witch-hunting as something related to law and order, superstition, religious impacts or related to property matters and its linkages with poverty (Geis, 1978; Goodin, 1981; Miguel, 2005; Rabia, 2005) and climate and its relation to food crop failure and income shocks. This is because, during the period of extreme rainfall resulting in droughts leading to poor harvest and near feminine condition in poor household areas, witchcraft murders increase in order to safeguard near subsistence consumption nutrition level by eliminating older members in the area (Behringer, 1999; Cohen, 1941; Cohn, 1990; Miguel, 2005; Pfister, 2007). Further, it has been also related to politics intermingling with nonconformity of civil religion in society and social disorganisation leading to chaos, segregation and formation of a new political party and thereby, witch hunt was seen as a means to suppress the upheaval of traditional order. Reference may be given to one such studies conducted by Bernhard, 2004 on witchcraft trails of Atlantic and Bermuda between 1645 to 1647 . It was seen that when there was nonconformity with the existing administration which was in that time ruled by church clergy, a group of independent puritan formed new group and challenged the colony government. Meanwhile the colonised power of England was facing huge challenged on home ground, where religious turmoil coupled with devastating civil war, provided fertile ground for witch hunts (Bernhard, 2010; Kapur, 1983). This political and religious upheaval had waves in tiny country of Bermuda where the ruling administration, used witchhunt as a means to blame someone of rising political upheaval. Nonetheless, the dark side of kinship, marriage customs, and polygenic societies has been the main focus of many studies (Behringer, 2004, 39; Feng, 2018). This research, however, is on the witch-hunting practices of Assam.

The state of Assam, located in the North-Eastern part of the country India, has been a significant hotspot of occurrence of this crime bearing deeper gripping roots mostly in tribal society (Bhattacharya, 1994). One hundred ninety-six 
cases have been registered under this head between 1989 and 2015 in police records, which is a severe quandary to this advancing society. However, this is merely on the scanty proportion of actual happening as most of it goes unreported and unknown. This observation is similar to various forms of crime against women which also remains unreported for various reasons (Bhattacharyya, 2015; Beniwal, 2017; Mukherjee et al., 2001). Nonetheless, considering the seriousness of witch-hunting practices, since 1995, it has been incorporated in the realm of crime against women in the country. The recurring instance of witch hunt in the state along with voices of pressure groups has forced Assam government to enact Assam Witch Hunting (Prohibition, Prevention, and Protection) Act, 2015 and made an offence under the act as non-bailable, cognisable and non-compoundable, torturing of women in the name of hunting down witches. Some stringent clauses integrated into the act includes maximum imprisonment term of three years to life imprisonment and a fine amount ranging between five thousand to five hundred thousand. The most significant clause of the bill is that Section 438 of Indian Penal Code (IPC) ${ }^{1}$ will not apply in cases of witch hunt, and with this the provision of getting anticipatory bail is wiped out in such cases. The bill further acts to provide rehabilitation to the victims (Saikia, 2017).

Before discussing how exactly crime or violence against women is plaguing the society like termites, the understanding of the term is utmost essential (Borah \& Das, 2018). The generic "gender blind use of the term violence" obscures the gender-specific forms of cruelty and attacks experienced by the woman alone (Vauquline, 2006, 2). Violence against women also includes - any acts of gender-based violence that results in, or is likely to result in, physical, sexual or psychological harm or suffering to women, including threats of such acts of coercion or arbitrary deprivation of liberty,

\footnotetext{
${ }^{1}$ Section 438 of Indian Penal Court: This provision allows a person to seek bail in anticipation of an arrest or accusation of having committed a non- bail able offence.
}

whether occurring in public or private life (United Nations General Assembly, 1993). Analysis of crime rate against women (as depicted by official records) in India reflects a very surprising and essential facet which needs attention. The western part and central of the country especially the districts of Haryana (75.7), Madhya Pradesh (65.5), and Rajasthan (81.5), Telangana (83.1), Delhi (184.3) and Chandigarh (64.8) falls in very high crime against women zone. ${ }^{2}$ Coincidently from early time these areas were considered as gendered unfriendly states. However, like the scenario in elsewhere in India, a similar picture echoes as we have a glimpse of the crime statistics of Assam (131.3) in 2016 which is more than twice of the national average of 53.6 (Crime in India, 2016). This gives a very depressing picture to an area where cases of dowry and bride burning were seldom heard off.

Witchhunt, an infectious practice affects both the sexes, but due to its high propensity of female victims, it is generally regarded as a gendered practice. Though a considerable research on European and African witch hunt has been made worldwide along with many studies in Indian witchcraft mainly focusing on the Adivasi community of the country (Banerjee, 2017; Chaudhuri, 2008; Chaudhuri, 2012; Chaudhuri, 2014) but there is a great scarcity of any comprehensive study on witch-hunting practices of Assam. Alongside, there is also a lack of cross-community genesis of witchcraft and therefore, this study aims to address the gap.

The research addresses the issue from the perspective of a crime specifically in the realm of crime against women (spatially and temporally) having cross-community dimensions in customary beliefs of society. Further, the research also tries to illuminate the causal and consequential purview of the socially sanctioned violence, highlighting the role of ojhas (village medicine men). The methodology is discussed in the next section.

\footnotetext{
${ }^{2}$ The parentheses display the rate of crime.
} 


\section{Methodology}

\section{Data Sources}

This research is based on both primary and secondary sources of data. Primary sources include the collection of data on different aspects of witch-hunting from the field using a structured questionnaire. Secondary sources include the collection of data from different government agencies, newspapers, journals, books and others. Interviews and cases studies were used to collect data from the victims, instigators, ojhas and other persons involved in cases of witch hunts. The victims were randomly chosen through a snowball sampling method in each of the villages in each district (GoalparaBarjhara, Jurigaon and Thakurvilla. KokrajharBhatipara, Sutarpara and Habrubari. Sonitpur- 4 no. Lakhipathar and 1 no Bhimajuli. JorhatBalijara, Borduar, Madhyam bhahphala. Sivsagar- Gorbhanga, Liabil and Sikarigaon) ${ }^{3}$ for in-depth interview. Due to the sensitivity of the cases, extreme care was taken to collect victim data so that, the victim does not face further dire consequences. This is because in many of the villages, the village committee prohibits them from speaking to the outsiders about the incidents linked to witch-hunting practices. Some of the cases are very fresh with accuser still in police custody and to avoid any kind of conflict situation precautions were taken. Twenty-two victims were considered for case study analysis. Out of them, seventeen are live victims, and five victims are dead. Interviews were conducted with live victims. Whereas, in the case of dead victims, the interview of family members were taken. Most of the victims were interviewed in their houses/villages where the cases have occurred. Victims/relatives of few fresh cases were called upon to the local police station as it was not possible to get an interview in the village. Names of all the victims are changed to maintain privacy.

\section{Location and Setting}

Assam, situated in the North-Eastern part of India, is located between $2408 / \mathrm{N}$ to $2802 / \mathrm{N}$ and $89042 / \mathrm{E}$ to $960 \mathrm{E}$ covers an area of $78,438 \mathrm{sq} \mathrm{km}$. It has a population of $31,169,272$ (2011). The literacy rate of the state is 73.185 and has a sex ratio of 954 females per 1000 males. Out of 35 total districts present in state of Assam, 27 districts (present in 2015) have been considered as a part of the study area because of the unavailability of boundaries of recently formed districts (see, Figure 1).

Witch-hunting cases are found to be occurring in 20 districts of Assam out of 27 (new districts have not been included due to unavailability of data).

The cases were found to be highest among twenty districts which included Kokrajhar (55 cases), Sonitpur (17 cases), Goalpara (20 cases), Udalguri (14 cases), Chirang (19 cases), Baska (11 cases), Jorhat (16 cases), Sibsagar (8 cases) (Figure 2). Out of eight districts Kokrajhar, Udalguri, Chirang, Baska and Goalpara falls under Lower Assam region with the cases of witch-hunting being dominant among the Bodo tribes except for in Goalpara where the cases were prominent among the Rabhas. Sonitpur falling under Upper Brahmaputra valley (Northern Bank) records the occurrence among a mixed group of Karbi, Tea tribes, Bodo. Jorhat including Majuli and Sivasagar falling under Lower Brahmaputra valley (Southern Bank) has maximum occurrence of witch-hunting cases amongst the Misings, Deuri and Ahom tribes.

In order to make a comprehensive study of the practice of witch-hunting among different tribal and nontribal communities, the final selection of survey area included the districts of Goalpara, Kokrajhar, Sonitpur, Jorhat, and Sivsagar taking into consideration the highest number of registered cases and also including diverse social and ethnic communities (Figure 2).

\footnotetext{
${ }^{3}$ The parentheses displays the surveyed districts along with surveyed villages.
} 


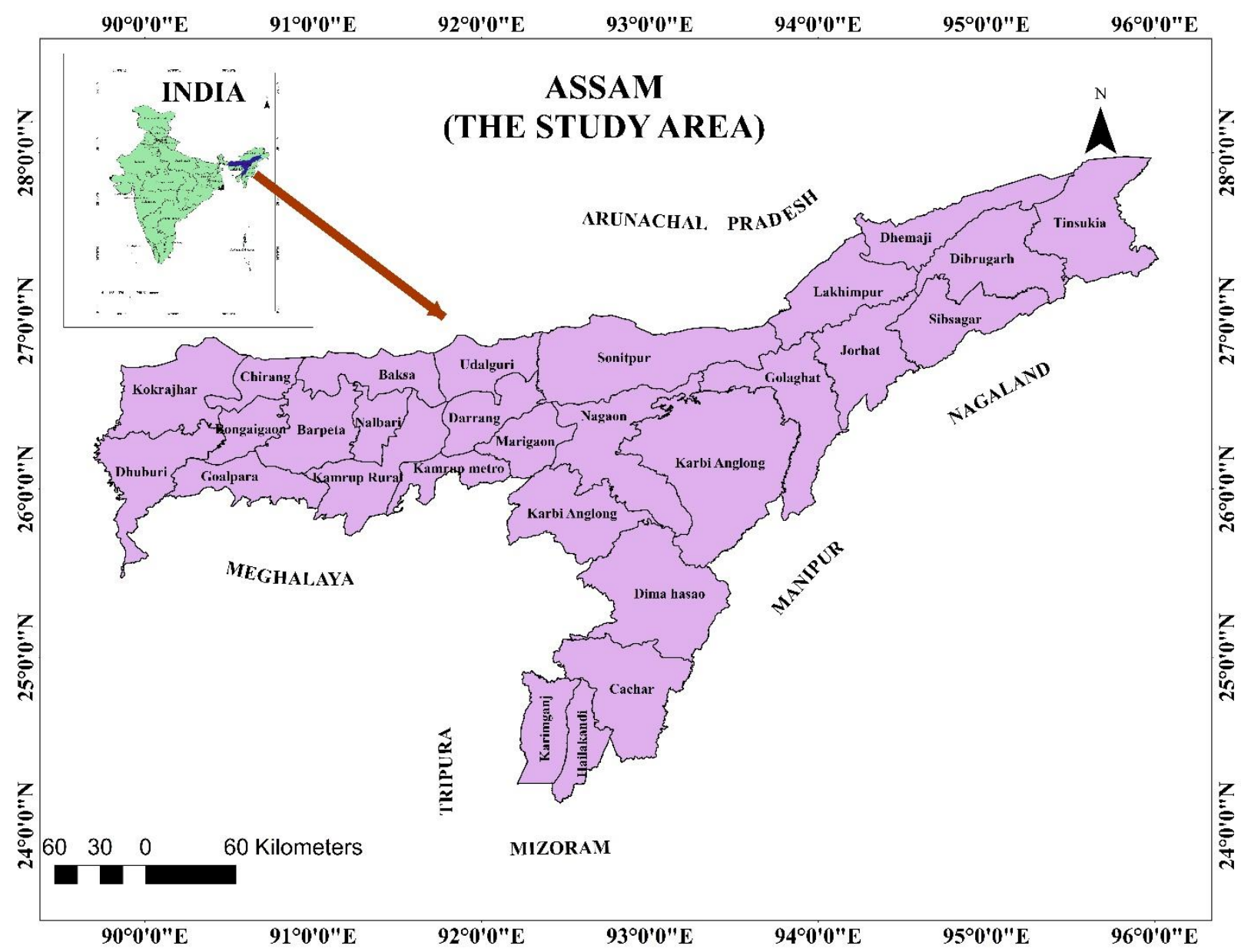

Figure 1: Location of the Study Area

Source: Prepared by the Authors in Arc G.I.S 10.2.1 


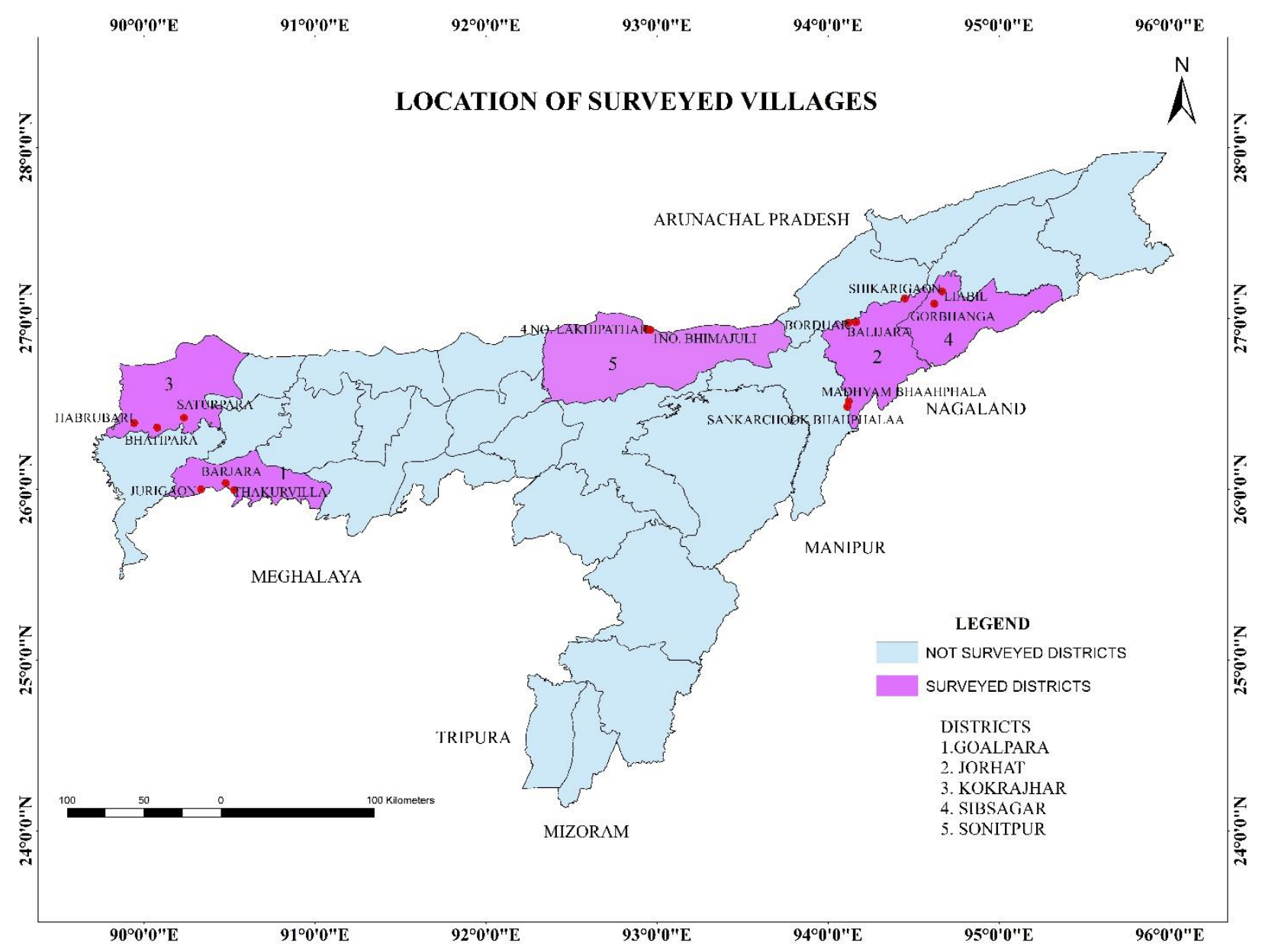

Figure 2: Location of the Survey Area Villages in Selected Districts. Source: C.I.D. Assam. Prepared by the Author in Arc G.I.S 10.2.1

\section{Witch-hunting as a Phenomenon}

Witch-hunting, literally meaning hunting of a witch who is believed to be inflicting harm to lives of other people has been a cause of severe moral panic and mass hysteria among many innocent people around the world. The patriarchal approach of (Dobash and Dobash, 1979), very clearly explains as to how patriarchy forms the base of any crime and very often women challenging the patriarchal societal norms and breaking the stereotype of ideal women have been found to be victimised (Behringer, 2004, 41). Patriarchal society has been a means for subjugating and suppressing women, whereby a secondary status is assigned to women in society. The role of women in the decision-making process of the family or the society continues to be meagre. In fact, even the decisions concerning woman's life is taken by the male members of the society throughout her life cycle. Stereotypical gender roles assign certain places as domain of women which limits her boundaries assigning a secondary status. This secondary status also gives power to the male members of the society to control the lives of women as their personal property and justifies any act of violence committed against them (Bhattacharyya, 2015). Besides this, the menstruation cycle of women, which as perceived in societies of India as impure also leads to those exorcist practices (Vir, 2006). Tackling of these cases is perplexing, complex, intertwine and agitated as the entire community along with their customary religious and cultural belief system sanctions the punishment meted out to the accused witch, and the guilty are seldom punished. Moreover most of the cases are recorded under murder category which makes identification of cases even more difficult (Chakraborty \& Borah, 2013).

The term witch has two different meanings. On the one hand, it is used to identify an individual 
who practices black magic- a sorcerer; on the other hand, individuals who are accused of being supernaturally evil. This creates a prejudiced mindset (Das and Sharma, 2014). The following section discusses the witch-hunting scenario from Assam.

\section{Glimpses of Scenario from Assam}

Crime against women in Assam has been showing an ever-increasing trend in recent time, along with spurge in witch-hunting cases (Moorthy, 2015). Traditionally, witchcraft was a part of the social life of the tribal communities in Assam, but now it is increasingly expanding among the other communities as well as across the state (Omeo Kumar Das Institute of Social Science, 2015) This issue of (in) accessibility (Bhattacharya 1994, 18) in these cases acts as a trump card because the more inaccessible an area is, the more is the grip of the superstitious belief where it is very easy and safe to denounce anyone as a witch.

Assam, known as the land of tantra- mantra (magic), which has a number of folk tales of dead regaining life with the mantra and had been extensively used for the benevolent or malevolent purpose (Saikia, 2017; Sarma, 2014). Interestingly, much of the practice has survived over the years simultaneously with the advent of modernity. Modern and modernity can be regarded as two facets of the same coin. For the western world in the first half of the 20th Century, modernity meant new technological innovations, governance, and socio-economics. It refers to the new changes that have taken place in every facet of society mostly after the World War II when the entire society was blooming out of the shackles of age-old traditions towards a better innovative and technologically advanced society. However, the use of the concept of modernity in this research in relation to witchcraft is development of advanced medical facilities, better education system, advancement in transport and communication and diffusion of scientific milieu towards a rational development of the thinking process. Nevertheless, the practice of witchhunt and its belief is still prevailing among the communities where the incidence of daini dhora (witch catch) and daini (witch) are rampant. Everything bad which could not be explained by logic was related to the evil eye (nazar) in societies which lack enlightenment (Omeo Kumar Das Institute of Social Science, 2015; Dwyer, 2003, 72).

According to local parlance, daini is commonly used in case of women for describing a witch in Assam. The Ojha, Bez or Deodhani (all names for witch doctors) do the task of identifying witch, the aftermath of which she is either banished from the community or killed.

Fluctuation trend is being seen in respect of official records (2008 to 2014) in the state of Assam, which is just a small proportion (Figure 3 ). As most of the cases go unreported in the name of the social and internal matter of village jurisdiction. Silent killing takes places in many areas to win over the demon that the villagers assumes. The cases of witch-hunting are found in certain pockets of Assam which includes Sonitpur, Darrang, Goalpara, Sivsagar, Tinsukia (Figure 4). The local and nuanced socio-cultural norms like rituals of Mangal Sowa (knowing fortune by means of astrology), belief in incarnation of God and Goddess in human beings during Kherai Puja (special ritual) of Bodos and Kechaikhati Puja (special ritual) of Deori, purification rituals with the advice of Mibu (priest) in the Misings of these areas seems to have influenced the occurrence of cases of witch-hunting as they have a low sex ratio, literacy and work participation and coincidently have the highest proportion of the population in Scheduled tribes category. The genesis of this menace is discussed below.

\section{The Genesis of Witchcraft in Assam}

The prevalence of witch-hunting among the different aboriginal communities of Assam can be traced back from their genesis of cultural beliefs and traditional values. As already mentioned above, prominent adherent believers include the Rabhas, Misings, Bodo, Adivasis, Ahom, Deuris, Garo. It, therefore, turns out to be utmost important to study more in-depth into the beliefs and customs of these communities. 


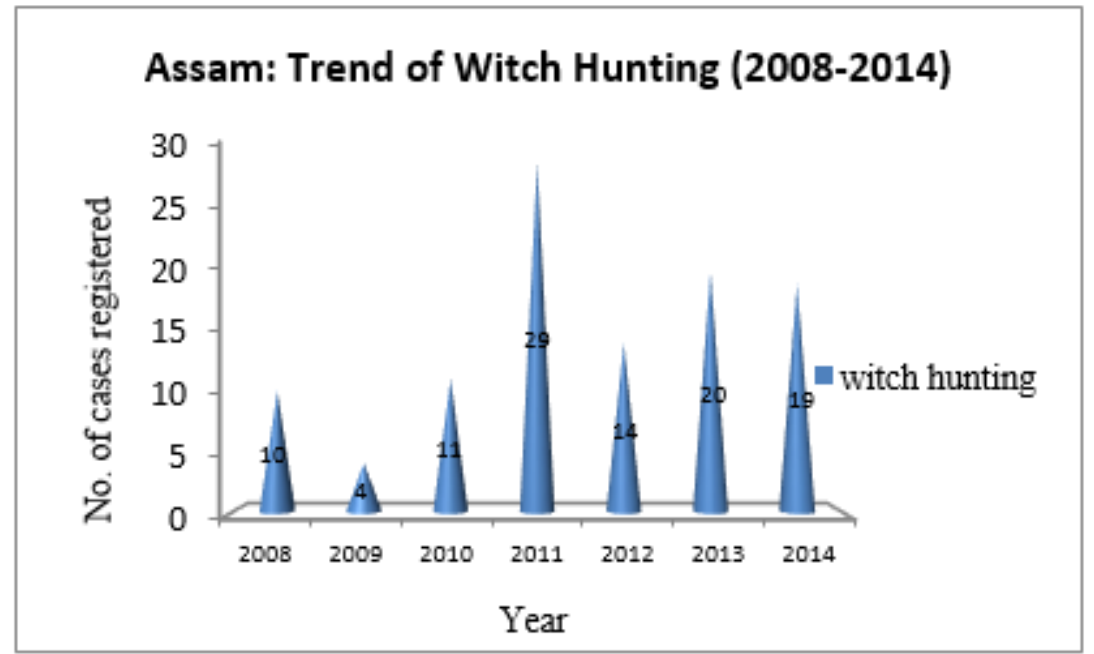

Figure 3: The Trend of Witch hunt in Assam

Source: C.I.D. Office, Assam

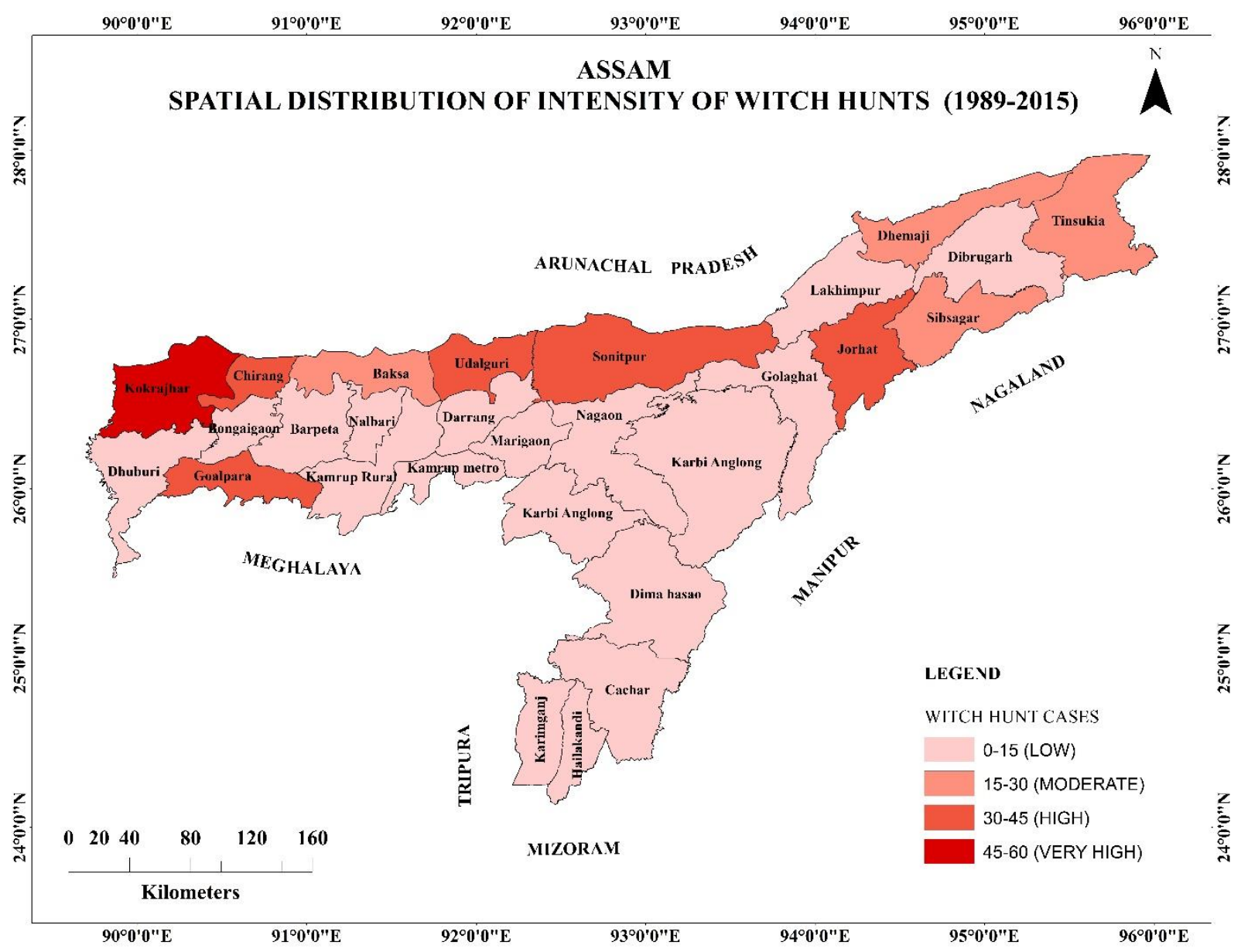

Figure 4: Map Showing the Spatial Distribution of Witch Hunting Cases in Assam Source: C.I.D Assam

Rabhas are a distinct racial community having unique practices relating to marriage, birth, and death and are one of the most conservative groups in the state having rigorous doctrines among them. They are stern believers of animism and relate everything to malevolent deities; dwelling of witches on seora (a kind of bush). They have two specific rituals: bai thakai and bai dhankai (special offering and a strong sacrosanct belief of magic, Daini (witch), Bej and 
Bejali (words used for local medicine men) in this society. Some beliefs include the domestication of bira (ghost), worship of Goddess Kali in the cremation ground, chaya mara (being invisible but perform acts) (Omeo Kumar Das Institute of Social Science, 2015; Hakacham, 2006, 2012). Accusation and trail process takes place in secret gathering in the community.

Similarly, the Bodo society is a historical believer in the existence of witchcraft and magic and regards witches as dread. They also believe in animism and consider bathou (God) as guardian of the family. Rites of Bodos consists of offerings, sacrifice, and prayers, and extant belief is still prevalent that supernatural creatures cause diseases. They are also a believer of Deodhania special dance performed by a person thought to be possessed (incarnation of spirit in the body) during kherai puja (offering). It is believed that during the time of dancing, the deodhanis can detect any such evil spirit in the village or any particular house and can also reveal if there is any daini or witch present (Charan, 2012; Daimari, 2012). The denouncement of a witch is kept utmost secret, and silently the victim is killed by cutting into pieces and burying it in the soil in different mounds.

The Misings, originally a hill tribe comprise strong belief on supernaturalism and animism. They believe that ui or $u y u$, two kinds of benevolent or malevolent spirits regulate the universe, and they are held responsible for the various phenomenon. They believe that spirits are everywhere and Mibu (the village priest) can appease these spirits. Offerings in the form of pigs, fowls, and apong (local beer) are made to the spirits. They also believe in yalo (a shadow of a soul) which can leave the body when a person is asleep, and it is the mibu who can bring him back by performing certain rituals. There is also another priest Deodhai known as Miru, later came to be known as Dondai. Mirus perform special kind of ritual during the night, and during that period they get possessed by deo (spirit). They believe in the existence of daini and fears that dainis can send tekeli ban (pitcher belly magic) and cause disease of pitcher's belly, which can be only cured by Dondai (Doley, 2012;
Bordoloi, 1987; Payeng, 2011; Padung, 2005). Acquisition of witches is carried out secretly, but the punishment is mostly in the form of exile from the village for some time, and in most cases, purification by a priest and mingling back to the community is natural, witch murders are not common.

Adivasis mostly resides in the tea gardens of Assam (Magar \& Kar, 2016). Although collectively known as Adivasi there are different sections among them having unique rights, rituals, and traditions. When somebody falls sick in their house, they usually take up to tantra mantra (magic) and offers special puja. The remains of ingredients used in puja (offering) are then placed in a dola (open plate) in crossroad without knowledge of others. They do not have any persecution process of a witch hunt, and once a group identifies a person to be a witch, silently the victim is killed by chopping off her head. The head is then offered to their Goddess Kali for doing away with misfortunes (Bhattacharya, 1994, 7). The factors leading to witch hunts are discussed below.

\section{Causal Factors Implicating Witch Hunts}

Various structural and individual factors undermine the targeting of individuals as witches. These people mostly live in interior remote areas. 8 out of 15 surveyed villages are located around a distance of $25 \mathrm{~km}$ minimum from the town centre. They lack consciousness about health and modern methods of treatment of disease. 67 per cent of the surveyed population refrain from going to the doctors (Rabia, 1983; Rabia, 2005), and even if they visit doctors, they first offer their offerings to local aie than or deo (local deity/ priest) (Das, 2012).

Besides this, the hygienic living condition is very poor, which causes many inert diseases, are thought to be the work of a witch, but actually, are caused by impure drinking water. It may be mentioned here that 90 per cent of the household do not treat water, nor do they have a proper source of drinking water. Almost all the villages lack proper sanitation facilities, earthen pits are widely present. Though toilets were built in some villages with the governmental initiative of Swacch Bharat Abhiyan their usage is 
circumscribed. Firstly, insights from field study suggest that due to miss management of governmental machinery and also the presence of mediators, the majority of the toilets were poorly constructed or half-built (Massive Corruption, 2019), and secondly, most of the surveyed area people are more comfortable, due to traditional mindset, with to defecate in open areas. These observations bear similarity with the observations made by Mishra (2018) and Singh \& Mishra (2019).

Very often diseases caused by consuming of dead animals get misinterpreted as the work of a witch, and accusation takes place in respect of the person with antagonist relation. Nonavailability of a reasonable standard of healthcare nearby makes them more dependent on local Ojha, where they fall prey to misguidance. Furthermore administrative failure in terms of providing basic needs and services available at a closer vicinity creates conditions, whereby diseases and routine illness are common and fatal. Lack of consciousness and knowledge about many diseases and illness forms the backbone in most of the cases of witch-hunting (Bhattacharya, 1994, 2). Despite the Right to Education policy of the Government of India, the literacy level of the people, especially those belonging to the Scheduled Castes and Scheduled Tribes population of the state are very poor (Barooah, 2014; Das, 2012; Das and Das, 2018; Kar, 2002). Getting insights from the fieldwork and literature review, the causation can be classified under broad overlapping themes as:

\section{IIInesses, Death, and Tragedies}

Illness or death of a human being or animal, inability to conceive, the birth of stillborn babies, even sometimes illness or death of victims' own children led to attribution to the victim. The attribution becomes more natural if the victim shares physical and familial proximity with instigators' family.

Cases of Jyoti Sangma, Jona Rabha, Biru Rabha, Pamii Orang, Purnali Pegu can be cited as examples. Jyoti Sangma was accused as a witch by a fellow villager when his son died of diarrhoea and lack of proper medical care.
Similarly, Jona Rabha was accused by her neighbour who was suffering from prolonged illness on the pretext of seeing her as a witch in his dreams. Seemingly, in the case of Biru Rabha whose husband was suffering from cancer and Ojha was unable to cure it, one of her relatives asserted her as a witch.

Pammi Orang was accused as a witch by the village priest on the death of her granddaughter. Purnali Pegu was accused by a fellow villager as a witch who was suffering from chest pain. All these victims were on suspicion of causing diseases and death among the villagers.

\section{Jealousy, Animosity and Conflict}

Jealousy, Animosity and Conflict often, inconsequential or random events such as repeated bad dreams, death on account of an undiagnosed illness, and an altercation with the victim see to trigger such accusation where preexisting conflict, tension jealousy helps the instigator to tackle personal grudges with the victim by a socially sanctioned means (Panthers of law and Development- PLD, 2014). The symbolic interaction theory of Mead (1918), Blumer (1973) and Beker can be cited here explaining the underpinning cause of crime; that provocation or any activity done by the victim does not always lead to such violence, but it is a means which offender use to achieve his/her end. Moreover as stated by symbolic interaction, it is from the social interaction of victim and offender that crime takes places. The process of social interaction and meaning that is given to a certain activity in a society that instigates or deviates crime, labelling and stigma play an important role. An offender always refrains from committing a crime if he has fear of being labelled as a deviant from society. But since in case of witch-hunting the entire society sanctions the violence so the offender uses violence and support of the members of society to achieve his ends and settle his grudges (Vir, 2006).

The cases of Ruhumi Rabha, Ani Rabha, Mahi Pegu Doley, Rash Konwar depicts the factual social reality as to how jealousy leads to witchcraft cases. 
Ani Rabha, a middle-aged woman, suffered the grudges of fellow villagers for her self-sustaining living. Moreover her husband abstained from consuming alcohol which was a common habit among the Rabha Community.

Mahi Pegu Dolley was accused as a witch due to her growing prosperity. Firstly she and her family had been successful in buying a pond/fishery along with her acquiring a job in village Anganwadi centre. She acquired the job by competing with her fellow villager cum relative which made her relatives envious of her and lead to the acquisition.

\section{Material and Economic Reasons}

In most of the cases, the sticking factors appear to be land disputes between parties, intentions to grab victim's property, to lay illegitimate claim over the property and material resources, jealousy regarding economic prosperity of the victim leading to the targeting of a witch. As described in rational choice theory (Cornish and Clarke, 1986) crime is committed by the preferences or choice that an offender makes among the accessible options by weighing his benefit. An offender always abstains from such a crime that has risk and has chances of being penalised. In witch-hunting cases also the accusers weigh his benefit before committing the crime, and since easy escape is possible, accuser applies it as an easy means to achieve his ends (Vir, 2006).

Riatmoni Doley of Majuli clearly remembers the day when a mob attacked her suddenly on the pretext that she refused to follow a village priest. She recalls as to how her brother-in-law fueled the situation and chased them out of the home and grabbed their property.

Ruhmi Rabha of Goalpara narrates her story of a small fight regarding house boundary with her neighbour cum brother-in-law. Using some foul words from her led to the acquisition of her being a witch. She not only lost her property, but her livestock was also sold off by the villagers and made to pay a massive fine from the money which the family derived from construction work.

\section{Transgression, Non-Conformity Difference}

Transgression, Non-Conformity Difference particularly her assertiveness and characteristics that set the victim apart as different or transgressive, also become a reason for labelling. In a few cases, the victim's outspoken nature and assertive behaviour evoked suspicion within the community which fuelled the targeting (PLD, 2014).

The case of Jyoti Sangma confirms the fact that sometimes outspoken nature of women, can lead to no conformity and accusation. She had been an outspoken lady in the village community about hygiene, about good and bad habits, and many a times had caught the accuser redhanded in stealing.

\section{Inauspicious single women}

Patriarchal society like India, regards a separated or widowed as inauspicious in society, and this subconscious mind or prejudiced view forms the bases of such witch-hunting cases. They become a suitable target in the absence of any capable guardian becomes an easy prey as explained in routine activity theory (Cohen and Felson, 1979). As asserted in the theory, three necessary conditions are prerequisite for occurrence of a crime-suitable target, absence of capable guardian and a likely offender. It gives more importance to the environment and situation than individual responsible for creating possibilities of crime. Since all the prerequisite falls in right position in case of single women a suitable target, and patriarchal mindset- the situation in the presence of any person(offender) who can firmly assert her as a witch, single women falls victim to the social dilemma (Vir, 2006).

One of the most exciting facets of these tribal communities is their own local brewed alcohol which forms an indispensable part of the social life. Prominent among them are Haria among Tea tribes, Nogen and Poro Apong and Sai mod among Mising, Rohi and Saj among Ahoms, Zwu or Zu mai among Bodos. Many times as seen in most of the cases, excess alcoholism by the victim or other members of society, misspelt or 
foul words or self-acquisition aggravates the scenario leading to acquisition.

Khedai Rabha of Goalpara is believed to be under the influence of alcohol when she uttered some illogical facts, and self-proclaimed herself as a daini, which was then misinterpreted by villagers as a witch.

Ruhmi Rabha of Goalpara asserts how she had a small fight with uttering of a few foul words eventually led to her victimisation. Her instigator brother-in-law served massive quantity of alcohol to the village jury and local bej before pronouncing her case verdict. The entire jury was so much under its influence of alcohol that the instigator could easily mould them in making his points valid.

However, the cause relating to sexual harassment or unfavoured sexual advancement as found in many parts of the world and also in different parts of India has not been found directly in the study areas and case studies, though slight inclination was present in one or two cases.

\section{Consequential After Effects}

Various factors give an intricate understanding of witch-hunting and intertwine to target and victimise particular individual and their near ones. The cases of witch-hunting might appear for outsiders as mere backwardness and superstitious belief, but the impact as a result of it on victim's life is far from the imagination of an outsider. The actual mental and emotional upheavals that the victim and family have to go through have far-reaching and deep scratches on their lives (PLD, 2014).

Verbal abuse seems to be the mere portion of what actual victimisation process results in. Others grievous consequences includes separation from children and family, forced stigma, isolation, threat, denial of access to public resources, forced displacement, loss of property and livelihood, payment of fines, oathtaking, performance of rituals, separation from community, humiliation and in most cases even to the extreme means of murder of the victim.
Serious economic consequences due to loss of livelihood were faced by the victim and family after accusation. Further, it was seen that this helplessness situation was taken advantage of by many to get hold of the property and other materials of the victim. Loss of access to public resources such as hand pumps, local shops, markets, community meetings, and centres are also widespread in cases. There is a common belief that a witch passes on the malevolent powers of witchcraft to her daughters, as a result, the unmarried daughters of a victim rarely get offer for marriage.

A variety of local common abusive words and labels that imply a witch (such as Diani, Dayan, Tikker, Hawa Khawa, Bateloga, Sikkhal, Boxi) are used. The consequences do not limit themselves to the victim alone but have several collateral victims.

\section{Conclusion}

The witch hunt is a superstitious practice that has been inflicting the lives of many since ages. Recurring instances of the crime is seen to occur among many tribal and aboriginal communities of Assam today. The genies of the practices have its roots in the tantra- matra rituals that have survived overages and has small reminisce of it in the traditional and customary beliefs of many tribal communities of the state. Accessibility, along with superstitions fuels the cases which lead to extreme brutalisation of the accused along with many collateral victims. It is thus utmost necessary to raise awareness, try to prevent and protect from becoming the victim of such a superstitious belief which leads into such a heinous crime.

\section{References}

Bailey, M. D. (2017). The European Witch-Hunt. Social History, 42(2), 281-282. DOI:

10.1080/03071022.2017.1290356

Banerji, B. (2017). Witch Beliefs and Violence Against Women Among Tribal Communities in The State of West Bengal. A Dissertation Submitted to the Department of Community Organization and Development Practice, School of Social Work, Tata Institute of Social Sciences, Mumbai. 
Barooah, M. G. (2014). Spatial Pattern and Variation in Literacy Among The Scheduled Castes Population in the Brahmaputra Valley, Assam. Space and Culture, India, 2(1), 24-32. doi.org/10.20896/saci.v2i1.68

Behringer, W. (1999). Climate Change and Witch-Hunting: The Impact of the Little Ice Age on Mentalities. Climate Change, 43, 335-351.

Behringer, W. (2004). Witches and Witchhubts, A Global History. Polity Press, USA, 14-241.

Beniwal, S. (2017). Crime Against Women in Chandigarh: A Study of Role of Police. An Unpublished PhD Thesis, Center for Police Administration. Panjab University, Chandigarh.

Bernhard, V. (2010). Religion, Politics, and Witchcraft in Bermuda, 1651-55. The William and Mary Quarterly, 67(4), 677-708. Retrieved on 13 July 2018 from,

https://www.jstor.org/stable/10.5309/willmary quar.67.4.0677

Bhattacharya. P. K. (1994). Witchcraft Among Santhals: A Case Study of Fifty Cases in Three Districts of West Bengal. Bankura: Liberal Association for Movement of People, Bankura, West Bengal, 1-63.

Bhattacharyya, R. (2015). Understanding the Spatialities of Sexual Assault Against Indian Women in India. Gender, Place and Culture, 22(9), 1340-1356. doi:10.1080/0966369X.2014.969684

Blumer, H. (1973). A Note on Symbolic Interactionism. American Sociological Review, 38 (6), 797-798. DOI: 10.2307/2094141

Booth, D. (2001). Dubious American Ideal: Gender and Historical Knowledge in the Crucible. Soundings: An Interdisciplinary Journal, 84 (1/2) (Spring/ Summer 2001), Penn State University Press, 31-49.

Borah, L. \& Das, M. (2018). Spatialities of Crime Against Women in Assam. Geographical Review of India, 80(1), 43-62.

Bordoloi, B. N., Sharmah Thakur, G. C., and Saikia, M.C. (1987). Tribes of Assam Part-I. Tribal Research Institute, Assam, Guwahati.
Bordoloi, B. N., \& Sharmah, Thakur G. C. (1988). Tribes of Assam. Part - II, Barmans Of Cachar, Hmars, Kukis, Rengma Nagas; Sonowal Kacharis, Zeme Nagas. First Ed. Guwahati. Tribal Research Institute, Assam, Guwahati.

Breslaw, E. (2003). Witches in the Atlantic World. OAH Magazine of History, Oxford University Press, 17(4), 43-47.

Chakraborty, J. \& Borah, A. (2013). WitchHunting in Assam: Strategizing Alternative Media for Women Empowerment and Overcoming Superstition. Journal of North East India Studies, 3(2), 15-24.

Charan, N. H. (2012). The Religion of the Bodos. In S. Shymkishore Singh (Eds.), Tribal religion. VII Part 7, History of Science Philosophy and Culture in Indian Civilization, PHISPC, Center for Studies in Civilization, New Delhi.

Chaudhuri, S. (2008). Tempest in a Tea Pot: Analysis of Contemporary Witch Hunts in the Tea Plantations of Bengal. An Unpublished PhD Thesis in Sociology, Graduate School of Vanderbilt University, Nashville, TN.

Chaudhuri, S. (2012). Women as Easy Scapegoats: Witchcraft Accusations and Women Targets in Tea Plantations of India. Violence Against Women, 18(10) 1213 -1234. DOI: $10.1177 / 1077801212465155$

Chaudhuri, S. (2014). Unusual Expressions of Social Protest Witchcraft Accusations in Jalpaiguri, India. CAS Working Paper Series Centre For The Study Of Social Systems Jawaharlal Nehru University, New Delhi, May 2014. CAS/WP/14-5.

Clarke, R., \& Cornish, D. (1986). Rational Choice, Unpublished Paper. In Alison Liebling, Shadd Maruna And Lesley Mcara (eds.), The Oxford Handbook Of Criminology (pp. 51). Oxford University Press, Oxford.

Cohen, J. (1941). Geography of Crime Against Women. Annals of The Academy of Political And Social Science, 217, 29-37.

Cohen. L. E. and Felson. M. (1979). Social Change and Crime Rate Trends a Routine Activity Approach. American Sociological Review, 44(4), 588-608. 
Cohn, E. G. (1990). Weather and Crime. The British Journal of Criminology, 30(1), 51-64

Crime in India, (2016). National Crime Records Bureau, Ministry of Home Affairs, Government of India.

Daimari. A. (2012). The Idea of 'Evil' Among the Bodos: Text And Context. In Prasenjit Biswas \& C.J. Thomas (2012, Eds.). Construction of Evil in North East India: Myth, Narrative And Discourse, Sage, New Delhi, 100-113.

Das, Itu. (2015). Witch-Hunting in the Present Scenario of the State of Assam - A Social Challenge. Assam College Teachers' Association Journal, XXXVII, 253-257.

Das, M. (2012). Witchcraft Among the Rabhas of Kamrup and Goalpara Districts of Assam. An Unpublished PhD. Thesis, Gauhati University, Guwahati.

Das, K. \& Das, M. (2018). Women and Wedlock: A Study on Female Marital Status Among the Hindus, Muslims and Christians of Assam. Space and Culture, India 2018, 6(1), 107-119.

doi.org/10.20896/saci.v6i1.294

Das, M. (2012). Tribal women of Assam. EBH Publishers, Guwahati.

Das, S., \& Sharma, D. (2014). Superstition, Superstitious \& Supplication Against Supernaturalism. In Dr. Anima Baishya (eds.). Phenomenon of Witch-Hunting A Major Challenge To Women (pp. 17-33). The Women Cell, S.B.M.S College, Sualkuchi.

Dobash and Dobash (1979). Violence Against Wives: A Case Against Patriarchy, New York Free Press, New York

Doley, B. K. (2012). The Religion of The Bodos. In S. Shymkishore Singh (ed.). Tribal Religion. VII Part 7, History of Science Philosophy and Culture in Indian Civilization (p. 69). PHISPC, Center For Studies In Civilization, New Delhi.

Dwyer, G. (2003). The Divine and The DemonicSupernatural Affliction and its Treatment in North India. Routledge Curzon, Taylor and Francis Group, London and New York.

Feng. D. (2018). Witch-Hunting, Cultural Revolution and the Bright Side of Kinship.
International Journal of Development Issues, 17(1), 87-101. https://doi.org/10.1108/IJDI-052017-0096

Geis, G. (2016). Lord Hale, Witches, and Rape. British Journal of Law and Society, 5(1), 26-44. http://www.jstor.org/stable/1409846

Goodin, R. (1981). Civil Religion and Political Witch Hunts: Three Explanations. Comparative Politics, 14 (1), 1-15.

Hakacham, U. P. (2006). Rabha Loka-Sanskriti. Publication Board Assam, Guwahati.

Himugu, J. H. (2015). Customary Beliefs and Tribal Laws About Witches and Witch Spirits in Miranda Forsyth. In Richard Eves (eds.). Talking It Through. Responses to Sorcery And Witchcraft Beliefs And Practices In Melanesia. The Australian National University Canberra, ACT 0200, Australia.

Homans, G. (1961). Social Behavior: Its Elementary Forms. Harcourt Brace Jovanovich, New York

Hsu, F. L. K. (1960). A Neglected Aspect of Witchcraft Studies. The Journal of American Folklore, 73(287), 35-38.

James, C. E. (2012).Witchcraft, Bureaucraft, and the Social Life of (Us) Aid in Haiti. Cultural Anthropology, 27(1), 50-75. DOI: 10.1111/j.1548-1360.2011.01126.x

Kapur, S. (1983). Witchcraft in Western India. Orient, Longman, Bombay

Kar, B. K. (2002). Women Population of North East India: A Study in Gender Geography. Regency Publications, New Delhi, 175-190.

Knut, R. (2014). A Shared Intentional Space of Witch-Hunt and Sacrifice. Ethnos, 79(3), 320341. DOI. 10.1080/00141844.2013.778308

Magar, C. K., \& Kar, B. K. (2016). Tea Plantations and Socio-Cultural Transformation: The Case of Assam (India). Space and Culture, India, 4(1), 25-39. https://doi.org/10.20896/saci.v4i1.188

Massive Corruption in Construction Of Swachh Bharat Toilets. (2019, January, 24). Pratidin Time. Retrieved on 24 January 2019 from, https://www.pratidintime.com/massive- 
corruption-in-construction-of-swachh-bharattoilets/

Mead, G. (1918). The Psychology of Punitive Justice. American Journal of Sociology, 23(5), 577-602. http://www.jstor.org/stable/2764150.

Miguel. E. (2005). Poverty and Witch Killing. The Review of Economic Studies, 72 (4), 1153-1172.

Mishra, S. K. (2018, April 11). Corruption In Swachh Bharat Raises A Stink. The New Indian Express. Retrieved on 11 April 2019 from, https://www.newindianexpress.com/states/odi sha/2018/apr/11/corruption-in-swachh-bharatraises-a-stink-1799790.html

Moorthy, Pa. (2015). Changing Trends in Crimes Against Women in India - An Empirical Study. An Unpublished PhD Thesis, Tamil Nadu Dr Ambedkar Law University, Chennai.

Mukherjee, C., Rustagi, P., \& Krishnaji, N. (2001). Crime Against Women in India Analysis of Official Statistics. Economic and Political Weekly, 36(43), 136-147.

Nath, R. (2016). A Game Theoretic Explanation of Witch Hunting with Special Reference to Assam. European Journal of Sociology and Anthropology, 1(2), 4. doi:10.20897/ejsa.201604

Omeo Kumar Das Institute of Social Science. (2015). Witch-Hunting in Assam, A Report by OKD Institute of Social Change And

Development, Guwahati.

Padung, N. (2005). Mising. In: Tom Mising Lokageet,Mibu-Miru, Mising Agam Kowbang (P. 47), Dhemaji.

Panthers of Law In Development, PLD (2014). Witch-Hunting in Assam: Individual, Structural and Legal Dimensions.

Payeng, S. (2011). Mising Janajati Samaj Aru Sanskriti,Mising Samajot Jadu, Tantra - Mantra And Marunaam. Jagaran, 35.

Pfister. C. (2007). Climatic Extremes, Recurrent Crises and Witch Hunts: Strategies of European Societies in Coping with Exogenous Shocks in the Late Sixteenth and Early Seventeenth Centuries. The Medieval History Journal, 10(1 \& 2), 33-73. DOI: 10.1177/097194580701000202
Rabia, A. A. (1983). Folk Medicine among the Bedouin Tribes in the Negev. Sde Boqer Campus, Ben-Gurion University of the Negev, Israel.

Rabia, A. A. (2005). The Evil Eye and Cultural Beliefs Among the Bedouin Tribes of the Negev, Middle East. Folklore, 116(3), 241-254. DOI: 10.1080/00155870500282677.

Rajaram, N. S. (1981). Indian Witchcraft. A Study in Indian Occultism. ON Abhinav Publications, New Delhi

Saikia, S. P. (2017). Witch-Craft, Witch-Trials and Witch-Hunting Perspectives - A Review with Special Reference to the Rabha Community of Assam. An Unpublished PhD Thesis, Department of Folklore, Gauhati University.

Sarma, P. J. (2014). Historical Myths or Mythological History: A Fresh Approach to Understand the History of Assam. Space and Culture, India, 2(3), 61-73.

https://doi.org/10.20896/saci.v2i3.94

Singh, A. and Mishra, R. (2019, January 10). Swachh Bharat Mission in Bihar Stumbling Due to Govt Corruption and Slow Construction of Toilets, Say Villagers. First Post. Retrieved on 10 January 2019 from, https://www.firstpost.com/india/swachhbharat-mission-in-bihar-stumbling-due-to-govtcorruption-and-slow-construction-of-toiletssay-villagers-5864481.html

Snodgrass, J. G., Lacy, M. G., Sharma, S.K., Jhala, Y.S., Advani, M., Bhargava, N.K., Upadhyay, C. (2008). Witch Hunts, Herbal Healing, And Discourses Of Indigenous Eco-Development in North India: Theory and Method in the Anthropology of Environmentality. American Anthropologist, 110 (3), 299-312. DOI: 10.1111/j.1548-1433.2008.00040.x

Tasa, D. (2012). Chah Janagosthir SomajSanskriti. Publication Board Assam, Guwahati.

United Nations General Assembly (1993). Declaration on the Elimination of Violence Against Women, A/RES/48/104,85th Plenary Meeting.

Vauquline, P. (2015). Socialisation Process, Power Relations and Domestic Violence: 
Marginal Voices of Assamese Women. Space and Culture, India, 3(2), 54-71.

https://doi.org/10.20896/saci.v3i2.155

Vauquline, P. (2006). Gender Related Crimes in Greater Guwahati Urban Area. An Unpublished
PhD Thesis, North Eastern Hill University, Shillong.

Vir, D. (2006). Violence Against Women and Their Exploitation in India. New Academic Publishers, New Delhi. 